\title{
Performance of Particleboard Made with Neolamarckia cadamba, Leucaena leucocephala, and their 50:50 Admixtures
}

\author{
Wan Mohd Nazri Wan Abdul Rahman, ${ }^{\mathrm{a}}$ Azematul Asma Md Yatim, ${ }^{\mathrm{b}}$ Rafizah Mansor \\ Manshor, ${ }^{\mathrm{c}}$ and Nor Yuziah Mohd Yunus ${ }^{\mathrm{a}, *}$
}

\begin{abstract}
The performance of a particleboard seems to be related to the chemical constituents of the species and the size distribution the particles. Neolamarckia cadamba (NC) and Leucaena leucocephala (LL) are fast growing species and good potential resources for particleboard production. This study examined the chemical contents of both species, as well as the mechanical and physical performance of particleboard made with $100 \%$ NC, $100 \%$ LL, and their 50:50 admixtures. High moisture resistance boards were prepared using melamine urea formaldehyde (MUF) at a content of 10,12 , and $14 \%$. The $30 \%$ extra buffering of LL translated to its lower performance for both mechanical and physical properties. The 50:50 admixtures provided enticing results, as it counteracts the impact of lowered performance of $100 \% \mathrm{LL}$. All boards passed the mechanical requirements of the BS EN 312 (2003) standard, but they did not meet the requirement for thickness swelling. The internal bond for cyclic test only failed for $100 \%$ LL with $10 \%$ resin added. With use of wax, the potential of improvement in swelling properties is possible.
\end{abstract}

DOI: 10.15376/biores.17.1.1868-

Keywords: Buffer capacity; Leucaena leucocephala; Neolamarckia cadamba; Particleboard; Performance

Contact information: a: Center of Wood Industries, Universiti Teknologi MARA Pahang, 26400 Jengka, Pahang, Malaysia; b: Faculty of Applied Sciences, Universiti Teknologi MARA, 40450 Shah Alam, Selangor, Malaysia; c: Malayan Adhesives and Chemicals Sdn. Bhd.40450 Shah Alam, Selangor, Malaysia; *Corresponding author: noryuziah@uitm.edu.my

\section{INTRODUCTION}

The need for fast growing species in particleboard production, particularly in Malaysia, prompted this study on two species, Neolamarckia cadamba (NC) and Leucaena leucocephala (LL). Fast replenishment capability of wood identified the potential of the two species. Neolamarckia cadamba is a good forest planation species with commercial return potential in 8 to 10 years (Trianoski et al. 2011; Wan-Abdul-Rahman et al. 2019). In Malaysia, NC trees have been planted in the State of Pahang and Perak, while the rest was planted in Sabah and Sarawak. Leucaena $L$ has a rotation cycle of 2 harvests of wood chips per year due to its capability to coppice. In a previous paper by Wan-Abdul-Rahman et al. 2019, the NC:LL particleboard was tested for 50:50 mix for impact of particle size and resin content. The emphasis here is the difference having 100\% NVC or LL against the mix. The unscreened material was used as this would be more representative of condition to be used in mill application. Additional properties of buffer capacity and chemical composition of the wood was also looked at. Buffering capacities but has been shown to impact resin behaviour during curing process (Policardi and Thebault 2020). 
Higher $\mathrm{pH}$ may cause the need to increase the acid quantity to allow same curing time. They also found that melamine urea formaldehyde (MUF) resin to be more effected by the $\mathrm{pH}$. Thus test of the buffering can indicated effects of the hot and water solubles on resin cure behaviour.

Having single species as a complete resource is the dream of a producer to reduce complication during board production. However, a mixed species scenario could be practical, and the combination of two fast growing species NN and LL would help in resource management. Thus, this study determined the mechanical and physical properties of particleboards made from unmixed and a mixture of NN and LL wood with different resin contents.

\section{EXPERIMENTAL}

The Educational Forest of Universiti Teknologi MARA Pahang, Jengka, Malaysia, provided the NC and LL wood. The diameter and height for NC and LL were reported previously (Wan-Mohd-Nazri et al. 2019). The density and moisture content of samples were tested. Even though the board making utilized the whole tree, the specific gravity (ISO 3131, 1975), chemical composition, and moisture content (TAPPI T 258 om-02, 2006) were done for 3 portions identified as the bottom, middle, and top. The buffer capacity study was done for the combined portions. For chemical analysis, the particles were ground to mesh size 40. Each species was tested for cold water solubility (TAPPI T207 cm-99 1999), hot water solubility (TAPPI T207 cm-99 1999), 1\% alkali solubility (TAPPI T212 om-02 2002), alcohol toluene solubility (TAPPI T204 cm-97 1997), ash content (TAPPI T211 om-02 2002), lignin content (TAPPI T222 om-02 2002), and holocellulose content (TAPPI T $203 \mathrm{~cm}-99$ 1999) following the TAPPI methods.

To prepare the particleboard, the wood was cut, chipped, air dried, screened to remove fines $(<0.5 \mathrm{~mm})$, and oven dried to below $10 \%$ moisture content. The particle size distribution of NC and LL was determined. For buffering capacity, $15 \mathrm{~g}$ of oven-dried chips were extracted using $200 \mathrm{~mL}$ of deionized water, gently boiled for $2 \mathrm{~h}$, and filtered after which the filtrate was cooled to room temperature and titrated with $0.01 \mathrm{~N} \mathrm{HCl}$ to $\mathrm{pH} 3$.

Particle size distribution was determined by the mechanical screening (sieve analysis) method (EN 15149-1 2010) for $100 \mathrm{~g}$ of wood particles.

Whilst the wood properties tested were for portions (top/middle/bottom) of the logs, the particleboard formed was from the combined fraction. The board production parameters were as follows: density, $700 \mathrm{~kg} / \mathrm{m}^{3} ; 12 \mathrm{~mm}$ thickness; length, $340 \mathrm{~m}$; and breadth, $340 \mathrm{~mm}$. The board making flowchart is given in Fig. 1.

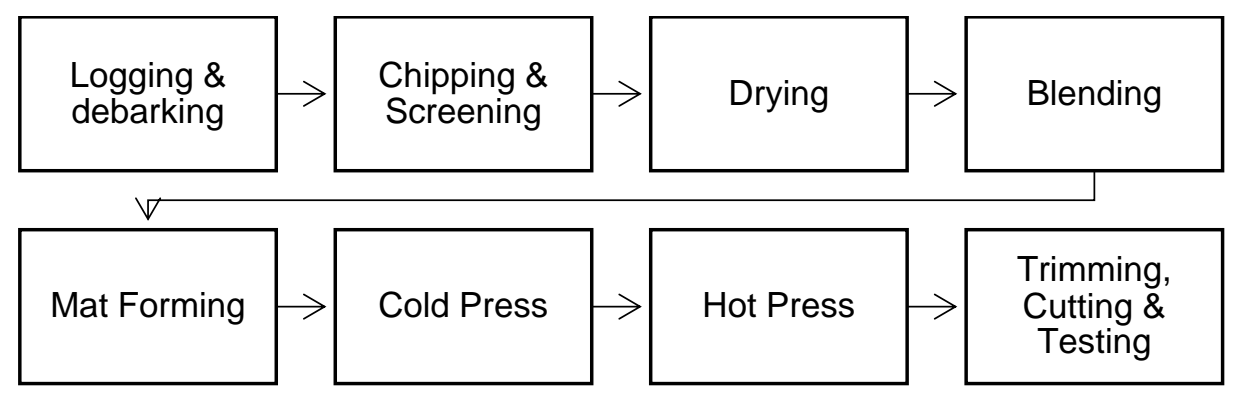

Fig. 1. Flowchart of particleboard formation 
Resin was added $(10,12$, and $14 \%)$ to unscreened particles; even distribution was ensured by 5 min blending after the last drop of resin was atomized. The resinated particles were formed, cold pressed for $10 \mathrm{~min}$, and hot pressed at $165^{\circ} \mathrm{C}$ for $6 \mathrm{~min}$.

Completed boards were conditioned at $20^{\circ} \mathrm{C}$ and $65 \%$ relative humidity for $24 \mathrm{~h}$. Test specimens were prepared according to relevant EN standards (EN 310, EN312, EN 317, and EN 319) for mechanical and physical properties determination. Because the melamine urea formaldehyde (MUF) resin has a high moisture resistance grade, the additional exposure test for internal bond (IB) was performed as per EN 321 (2002); the cyclic test consisted of a three-cycle accelerated aging treatment. All results were analyzed with IBM SPSS statistical 20 software (Armonk, NY, USA).

\section{RESULTS AND DISCUSSION}

\section{Wood Properties}

The physical properties of fresh wood depend on its species and on the sampling location such as trunk, sapwood, and heartwood; juvenile and mature wood; or branches and roots (Babinski et al. 2014). The wood properties such as specific gravity and moisture content are important when ensuring the suitability for different applications (Wahab et al. 2009). The average specific gravity and moisture content for NC and LL are shown in Table 1. The specific gravity for both species increased as the sampling location moved from the top to the bottom of the tree. The highest specific gravity for both species was at the bottom of the tree, with a value 0.45 for NC and 0.76 for LL. According to Lim et al. (2005), the density range of NC was from 290 to $465 \mathrm{~kg} / \mathrm{m}^{3}$, and it is classified as light hardwood. LL is medium hardwood (MTIB 2000). The specific gravity was significantly different between species and portions of wood tested (Table 2). The higher moisture content of NC reflected the porosity of the wood.

Table 1. Specific Gravity and Moisture Content of N. cadamba and $L$. leucocephala

\begin{tabular}{|c|c|c|c|}
\hline Species & Tree Portion & Specific Gravity & Moisture Content (\%) \\
\hline \multirow{3}{*}{$\begin{array}{c}\text { Neolamarckia cadamba } \\
\text { NC }\end{array}$} & Top & 0.36 & 93.72 \\
\cline { 2 - 4 } & Middle & 0.39 & 88.52 \\
\cline { 2 - 4 } & Bottom & 0.45 & 71.77 \\
\cline { 2 - 4 } & Average & $\mathbf{0 . 4 0}$ & $\mathbf{8 4 . 6 7}$ \\
\hline \multirow{3}{*}{$\begin{array}{c}\text { Leucaena leucocephala } \\
\text { LL }\end{array}$} & Top & 0.61 & 63.22 \\
\cline { 2 - 4 } & Middle & 0.67 & 55.06 \\
\cline { 2 - 4 } & Bottom & 0.76 & 52.11 \\
\cline { 2 - 4 } & Average & $\mathbf{0 . 6 8}$ & $\mathbf{5 6 . 8 0}$ \\
\hline
\end{tabular}

Table 2. Summary of ANOVA on Physical Properties

\begin{tabular}{|c|c|c|c|}
\hline SOV & Df & Specific Gravity & Moisture Content \\
\hline Species (S) & 1 & $806.45^{\star \star}$ & $47.90^{\star \star}$ \\
\hline Tree Portion (TP) & 2 & $64.74^{\star *}$ & $5.68^{\star}$ \\
\hline S x TP & 3 & $0.91 \mathrm{~ns}$ & $1.09 \mathrm{~ns}$ \\
\hline
\end{tabular}

Note: $\mathrm{SOV}=$ source of variance, $\mathrm{Df}=$ degree of freedom, $\mathrm{ns}=$ not significant, ${ }^{*}$ significant at $\mathrm{p}<$ $0.05,{ }^{* *}$ highly significant at $p<0.01$ 
The chemical compositions of NC and LL are summarized in Table 3. All values in LL were higher than NC, except for lignin content. For different tree portions, both species showed varying results. Cold water and hot water solubles, alcohol-toluene solubility, and holocellulose content of both species increased as the tree heights decreased. Cold and hot water percentage showed decreasing trends from top to the bottom portion of the tree (Table 3). The highest value of cold water was $6.17 \%$ in the top portion of LL, and the lowest was in the bottom portion of NC (2.26\%). The average cold water soluble value of LL $(5.45 \%)$ was higher than NC $(2.99 \%)$. Likewise, the hot water soluble value of LL $(5.98 \%)$ was higher than $\mathrm{NC}(3.62 \%)$. $\mathrm{NaOH}(1 \%)$ solubility of $\mathrm{NC}$ decreased with tree heights, while LL displayed the opposing trend. The ash content and lignin contents of both species increased from the top to the bottom of the tree. Values of NC differed from earlier work for CW, HW, and lignin (Jamaluddin et al. 2018; Wan-Abdul-Rahman et al. 2020). Results for LL were very similar to work by Muhammad Zulhilmi (2019) for all properties.

Table 4 shows the analysis of variance (ANOVA) of the effects of species and tree portion and their interactions on chemical properties. The two species were significantly affected for the cold water and hot water but insignificantly dependent on $1 \% \mathrm{NaOH}$ solubility, alcohol toluene solubility, ash content, lignin content, and holocellulose content. For tree portion, there was no significant effect for $1 \% \mathrm{NaOH}$ soluble and lignin content. The calculated values of chemical analysis for top, middle, and bottom was taken as average and used as basis of buffer capacity impact consideration.

Table 3. Chemical Compositions of N. cadamba and L. leucocephala According to Tree Portions

\begin{tabular}{|c|c|c|c|c|c|c|c|c|}
\hline Species & Portion & $\begin{array}{c}\mathrm{CW} \\
(\%)\end{array}$ & $\begin{array}{c}\mathrm{HW} \\
(\%)\end{array}$ & $\begin{array}{c}1 \% \mathrm{NaOH} \\
(\%)\end{array}$ & $\begin{array}{c}\text { Ash } \\
(\%)\end{array}$ & $\begin{array}{c}\text { Alcohol } \\
(\%)\end{array}$ & $\begin{array}{c}\text { Lignin } \\
(\%)\end{array}$ & $\begin{array}{c}\text { Holo } \\
(\%)\end{array}$ \\
\hline \multirow{4}{*}{ NC } & Top & 3.75 & 4.23 & 12.08 & 0.52 & 2.81 & 22.76 & 80.64 \\
\cline { 2 - 9 } & Middle & 2.95 & 3.88 & 12.62 & 0.62 & 2.75 & 22.79 & 79.30 \\
\cline { 2 - 9 } & Bottom & 2.26 & 2.76 & 14.43 & 0.89 & 2.20 & 24.87 & 77.83 \\
\cline { 2 - 9 } & Average & $\mathbf{2 . 9 9}$ & $\mathbf{3 . 6 2}$ & $\mathbf{1 3 . 0 4}$ & $\mathbf{0 . 6 8}$ & $\mathbf{2 . 5 8}$ & $\mathbf{2 3 . 4 7}$ & $\mathbf{7 9 . 2 5}$ \\
\hline \multirow{4}{*}{ LL } & Top & 6.17 & 6.69 & 14.00 & 0.65 & 2.84 & 20.02 & 80.76 \\
\cline { 2 - 9 } & Middle & 5.38 & 5.71 & 13.98 & 0.75 & 2.52 & 23.12 & 79.14 \\
\cline { 2 - 9 } & Bottom & 4.81 & 5.55 & 12.93 & 0.87 & 2.10 & 25.03 & 78.49 \\
\cline { 2 - 9 } & Average & $\mathbf{5 . 4 5}$ & $\mathbf{5 . 9 8}$ & $\mathbf{1 3 . 6 4}$ & $\mathbf{0 . 7 6}$ & $\mathbf{2 . 4 9}$ & $\mathbf{2 2 . 7 2}$ & $\mathbf{7 9 . 4 6}$ \\
\hline
\end{tabular}

Note: Values are averages of three determinations; $\mathrm{CW}=$ cold water soluble; $\mathrm{HW}=$ hot water soluble; $\mathrm{NaOH}=$ alkali soluble $(1 \% \mathrm{NaOH}) ; \mathrm{AT}=$ alcohol toluene soluble; Holo = holocellulose

Table 4. Summary of ANOVA on Chemical Properties

\begin{tabular}{|l|c|c|c|c|c|c|c|c|}
\hline SOV & Df & $\mathrm{CW}$ & $\mathrm{HW}$ & $\begin{array}{c}1 \% \\
\mathrm{NaOH}\end{array}$ & Ash & AT & Lignin & Holo \\
\hline Species $(\mathrm{S})$ & 1 & $\begin{array}{c}496.01^{*} \\
*\end{array}$ & $76.26^{* *}$ & $1.79 \mathrm{~ns}$ & $4.05 \mathrm{~ns}$ & $2.13 \mathrm{~ns}$ & $0.34 \mathrm{~ns}$ & $0.83 \mathrm{~ns}$ \\
\hline Portion $(\mathrm{P})$ & 2 & $55.47^{\star *}$ & $7.71^{* *}$ & $0.70 \mathrm{~ns}$ & $19.25^{\star *}$ & $8.00^{*}$ & $2.60 \mathrm{~ns}$ & $40.15^{\star *}$ \\
\hline
\end{tabular}

Note: SOV $=$ source of variance, $\mathrm{Df}=$ degree of freedom, $\mathrm{ns}=$ not significant, ${ }^{*}$ significant at $\mathrm{p}<$ $0.05,{ }^{* *}$ highly significant at $\mathrm{p}<0.01 ; \mathrm{CW}=$ cold water soluble; $\mathrm{HW}=$ hot water soluble; $\mathrm{NaOH}=$ alkali soluble $(1 \% \mathrm{NaOH}) ; \mathrm{AT}=$ alcohol toluene soluble; Holo = holocellulose

\section{pH Value and Buffer Capacity}

Xing et al. (2004) noted that the $\mathrm{pH}$ and buffering capacity of raw fiber materials is important for understanding the effects of raw material on the curing rate of resin used for panel manufacturing, especially with some less desirable wood materials such as bark, 
top, and commercial thinning. All portions were mixed with equal proportion prior to extraction. This was done as the particleboard will be using a mixture of all the portions. Upon extraction by boiling, the average $\mathrm{pH}$ of LL (5.62) was slightly more acidic than NC (5.99). Interestingly when compared (Fig. 2), the $\mathrm{pH}$ drop of $\mathrm{NC}$ was sharper at the first $\mathrm{mL}$ addition and the drop of $\mathrm{pH}$ continued to decrease at a faster rate than LL. Initially, for $\mathrm{NC}$ there was a rapid change until $4 \mathrm{~mL}$ of acid was added, then a steadily plateau to $\mathrm{pH} 3$ as $7 \mathrm{~mL}$ of acid was added. Based on the acid titration result, LL showed a steady change in the $\mathrm{pH}$. Approximately $9 \mathrm{~mL}$ of acid was added to change the LL to $\mathrm{pH}$ 3.0. The $\mathrm{NC}$ solution needed $30 \%$ less acid to reach the benchmark of $\mathrm{pH} 3$. The difference in amount of acid needed indicates a potential curing difference for the two species. The particleboard produced in this study utilized MUF, an acid-cured resin.

The difference in behaviour of the NC and LL could be linked to the level of cold and hot water solubles. The NC had an average of $2.99 \%$ for cold water and $3.62 \%$ for hot water. For LL, the values were 5.45 and 5.98, respectively. At the onset, the LL had a higher concentration of water-soluble material, which could account for the steady reaction toward the $\mathrm{HCl}$. For $\mathrm{NC}$, having a higher $\mathrm{pH}$ despite of the lower soluble content indicated the presence of a more alkaline based material, which reacts easily with acid to form salt.

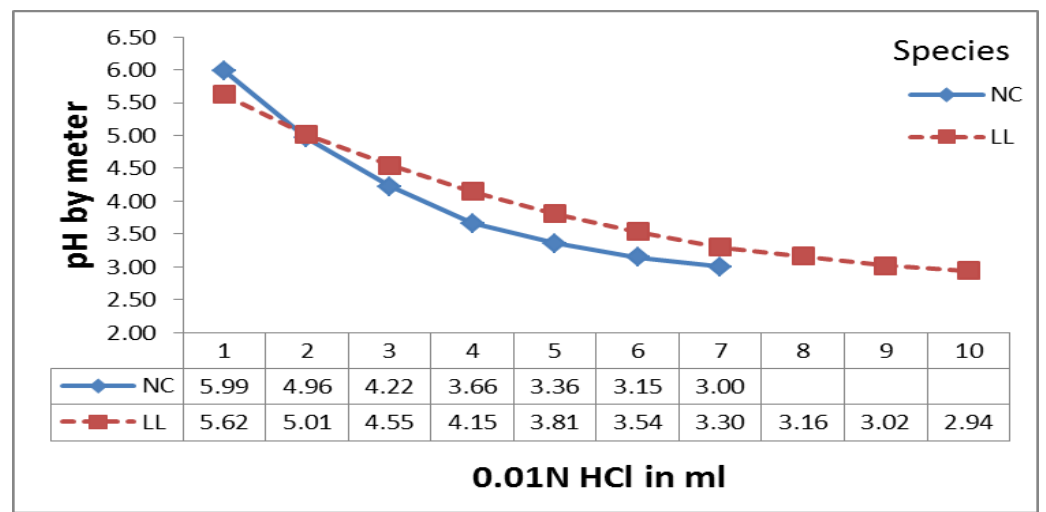

Fig. 2. Buffering capacity of unscreened N. cadamba (NC) and L. leucocephala (LL) to acid

\section{Particle Size Distribution and Bulk Density}

The particle size distribution of both species is given in Fig 3. Neolamarckia cadamba had a lower content of smaller particles than LL. The particle of NC was normally distributed, with $1.4 \mathrm{~mm}$ making up the highest percentage. Leucaena leucocephala particle distribution was skewed toward smaller sizes, where the highest value was for particle size of $0.5 \mathrm{~mm}$. The sieve size percentage showed that the overall NC size ratio was $47: 53$, for the $1.4 \mathrm{~mm}$ and lower against the above $1.4 \mathrm{~mm}$ sieve size, respectively. The LL overall size showed an approximate ratio of 86:14 respectively for the same range. The particle size distribution plays an important role in bulk density, compressibility, durability, and flow-ability of densified products. Densified materials provide important information about quality and performance (Tumuluru et al. 2011; Guo et al. 2012; Zhang and Guo 2014).

The bulk density of NC and LL was 118.5 and $145.4 \mathrm{~g} / \mathrm{cm}^{3}$, respectively. They were significantly different at $\mathrm{p} \leq 0.05$. Protasio (2012) studied the effects of compaction ratio and bulk density on three different Eucalyptus species and found a direct correlation between these variables and the bending properties and inverse correlation with the thickness swelling of the resulting particleboard panels. 


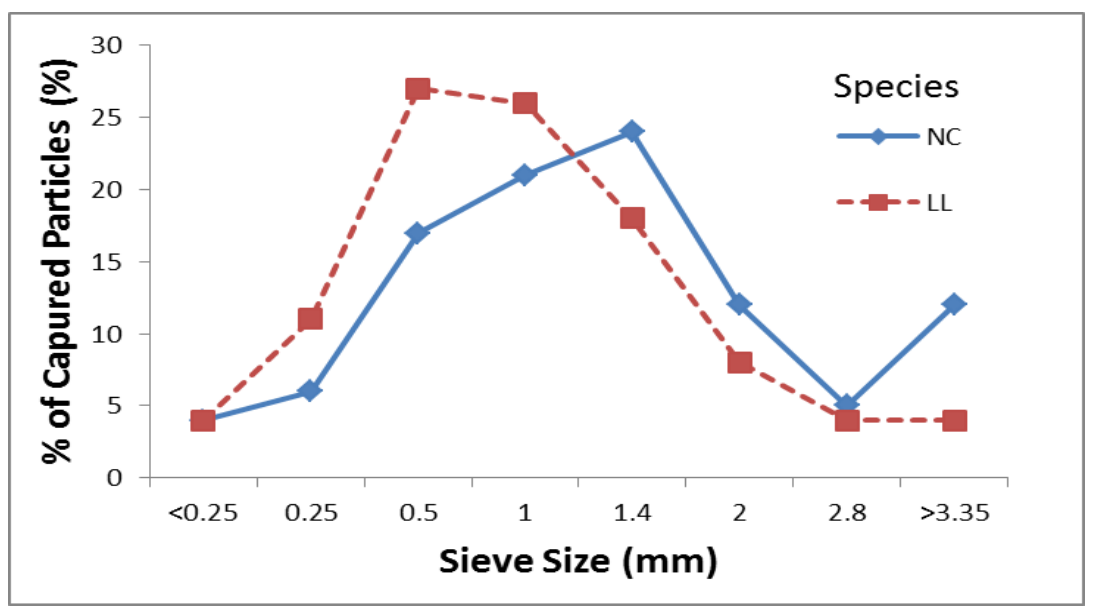

Fig. 3. Particle size distributions of $N$. cadamba and L. leucocephala

\section{Particleboard Properties}

Table 5 summarizes the physical and mechanical properties of MUF bonded particleboard made from NC, LL, and their mixed particles at three resins content. The performance of all boards met the BS EN 312 (2003) requirement for all tests except for thickness swelling (TS). The NC board with 14\% resin content showed the best performance. In general, LL performance was lower than NC and the 50:50 mixed particles.

Table 5. Physical and Mechanical Properties N. cadamba and L. leucocephala Particleboards with Different Resin Contents

\begin{tabular}{|c|c|c|c|c|c|c|c|c|}
\hline No. & Species & $\begin{array}{c}\text { RC } \\
(\%)\end{array}$ & $\begin{array}{c}\text { MOE } \\
(\mathrm{MPa})\end{array}$ & $\begin{array}{c}\text { MOR } \\
(\mathrm{MPa})\end{array}$ & $\begin{array}{c}\text { IB } \\
(\mathrm{MPa})\end{array}$ & $\begin{array}{l}\text { IB-CT } \\
(\mathrm{MPa})\end{array}$ & TS (\%) & WA (\%) \\
\hline 1 & NC 100 & 10 & $\begin{array}{l}3159 \\
(411)\end{array}$ & $\begin{array}{l}23.98 \\
(4.85) \\
\end{array}$ & $\begin{array}{c}0.71 \\
(0.23)\end{array}$ & $\begin{array}{c}0.18 \\
(0.03)\end{array}$ & $\begin{array}{l}23.24 \\
(9.89)\end{array}$ & $\begin{array}{c}88.85 \\
(13.19) \\
\end{array}$ \\
\hline 2 & NC 100 & 12 & $\begin{array}{l}3202 \\
(585)\end{array}$ & $\begin{array}{l}26.25 \\
(7.62)\end{array}$ & $\begin{array}{c}0.88 \\
(0.34)\end{array}$ & $\begin{array}{c}0.36 \\
(0.30)\end{array}$ & $\begin{array}{l}19.56 \\
(3.65)\end{array}$ & $\begin{array}{c}74.10 \\
(14.09)\end{array}$ \\
\hline 3 & NC 100 & 14 & $\begin{array}{l}3542 \\
(585) \\
\end{array}$ & $\begin{array}{l}27.59 \\
(5.40)\end{array}$ & $\begin{array}{c}0.87 \\
(0.33) \\
\end{array}$ & $\begin{array}{c}0.45 \\
(0.15) \\
\end{array}$ & $\begin{array}{r}15.36 \\
(2.04) \\
\end{array}$ & $\begin{array}{c}71.10 \\
(15.65) \\
\end{array}$ \\
\hline 4 & $\begin{array}{c}\text { NC:LL } \\
50: 50\end{array}$ & 10 & $\begin{array}{l}3060 \\
(483)\end{array}$ & $\begin{array}{l}23.28 \\
(5.15)\end{array}$ & $\begin{array}{c}0.70 \\
(0.40)\end{array}$ & $\begin{array}{c}0.15 \\
(0.03)\end{array}$ & $\begin{array}{l}24.63 \\
(5.71)\end{array}$ & $\begin{array}{c}84.32 \\
(13.13)\end{array}$ \\
\hline 5 & $\begin{array}{c}\text { NC:LL } \\
50: 50\end{array}$ & 12 & $\begin{array}{l}3147 \\
(633)\end{array}$ & $\begin{array}{l}23.57 \\
(6.03)\end{array}$ & $\begin{array}{c}0.79 \\
(0.41)\end{array}$ & $\begin{array}{c}0.23 \\
(0.01)\end{array}$ & $\begin{array}{l}22.90 \\
(2.43)\end{array}$ & $\begin{array}{c}75.85 \\
(14.57)\end{array}$ \\
\hline 6 & $\begin{array}{l}\text { NC:LL } \\
50: 50\end{array}$ & 14 & $\begin{array}{l}3522 \\
(441)\end{array}$ & $\begin{array}{l}26.56 \\
(4.16)\end{array}$ & $\begin{array}{c}0.82 \\
(0.37)\end{array}$ & $\begin{array}{c}0.41 \\
(0.01)\end{array}$ & $\begin{array}{l}19.38 \\
(1.89)\end{array}$ & $\begin{array}{c}72.29 \\
(12.88)\end{array}$ \\
\hline 7 & LL 100 & 10 & $\begin{array}{l}2699 \\
(507)\end{array}$ & $\begin{array}{l}20.76 \\
(4.20)\end{array}$ & $\begin{array}{c}0.69 \\
(0.19) \\
\end{array}$ & $\begin{array}{c}0.10 \\
(0.03)\end{array}$ & $\begin{array}{l}27.59 \\
(2.10)\end{array}$ & $\begin{array}{l}83.84 \\
(8.81)\end{array}$ \\
\hline 8 & LL 100 & 12 & $\begin{array}{l}2726 \\
(494)\end{array}$ & $\begin{array}{l}22.50 \\
(4.41)\end{array}$ & $\begin{array}{c}0.70 \\
(0.35)\end{array}$ & $\begin{array}{c}0.23 \\
(0.03)\end{array}$ & $\begin{array}{l}22.89 \\
(1.64)\end{array}$ & $\begin{array}{c}78.02 \\
(13.83)\end{array}$ \\
\hline 9 & LL 100 & 14 & $\begin{array}{l}3004 \\
(398)\end{array}$ & $\begin{array}{l}23.55 \\
(3.39)\end{array}$ & $\begin{array}{c}0.78 \\
(0.39)\end{array}$ & $\begin{array}{c}0.31 \\
(0.09)\end{array}$ & $\begin{array}{l}20.05 \\
(1.87)\end{array}$ & $\begin{array}{c}74.80 \\
(12.83)\end{array}$ \\
\hline \multicolumn{3}{|c|}{$\begin{array}{l}\text { Minimum requirement } \\
\text { EN } 312(2003)\end{array}$} & 2050 & 15 & 0.45 & 0.15 & 14 & - \\
\hline & & & $\begin{array}{l}\text { EN 310 } \\
(2003)\end{array}$ & $\begin{array}{l}\text { EN 310 } \\
(2003)\end{array}$ & $\begin{array}{l}\text { EN 319 } \\
(2003)\end{array}$ & $\begin{array}{l}\text { EN 321 } \\
(2002)\end{array}$ & $\begin{array}{l}\text { EN 317 } \\
(2003)\end{array}$ & - \\
\hline
\end{tabular}

(Standard deviation), NC = Neolamarckia cadamba; $\mathrm{LL}=$ Leucaena leucocephala; $\mathrm{RC}=$ resin content; $\mathrm{MOE}=$ modulus of elasticity; $\mathrm{MOR}=$ modulus of rupture; IB = internal bond; IB-CT = internal bond for cyclic test; TS = thickness swelling; and WA = water absorption 
Table 6 shows the ANOVA of the effects of species mix, resin content, and their interaction with particleboard properties. The species mix significantly affected the particleboard properties except for IB. For resin content, all test parameters were significantly affected. The interaction of species mix and resin content were significant only for TS and water absorption (WA).

Table 6. Summary of ANOVA on Particleboard Properties

\begin{tabular}{|l|c|c|c|c|c|c|c|}
\hline SOV & Df & $\begin{array}{c}\text { MOE } \\
(\mathrm{MPa})\end{array}$ & $\begin{array}{c}\text { MOR } \\
(\mathrm{MPa})\end{array}$ & $\begin{array}{c}\mathrm{IB} \\
(\mathrm{MPa})\end{array}$ & $\begin{array}{c}\text { IB CT } \\
(\mathrm{MPa})\end{array}$ & $\begin{array}{c}\text { TS } \\
(\%)\end{array}$ & $\begin{array}{c}\text { WA } \\
(\%)\end{array}$ \\
\hline $\begin{array}{l}\text { Species Mix } \\
(\mathrm{SM})\end{array}$ & 2 & $14.96^{* *}$ & $15.73^{* *}$ & $2.48 \mathrm{~ns}$ & $5.61^{* *}$ & $6.68^{* *}$ & $15.03^{* *}$ \\
\hline $\begin{array}{l}\text { Resin Content } \\
(\mathrm{RC})\end{array}$ & 2 & $15.28^{* *}$ & $11.76^{* *}$ & $6.6^{* *}$ & $28.47^{* *}$ & $105.26^{* *}$ & $44.18^{* *}$ \\
\hline SM $x$ RC & 4 & $1.19 \mathrm{~ns}$ & $0.42 \mathrm{~ns}$ & $0.38 \mathrm{~ns}$ & $0.30 \mathrm{~ns}$ & $8.01^{* *}$ & $3.78^{* *}$ \\
\hline
\end{tabular}

Note: $\mathrm{SOV}=$ source of variance, $\mathrm{Df}=$ degree of freedom, $\mathrm{ns}=$ not significant, ${ }^{*}$ significant at $\mathrm{p}<$ 0.05 , ** highly significant at $\mathrm{p}<0.01 ; \mathrm{MOE}=$ modulus of elasticity; MOR = modulus of rupture; IB = internal bond; IB-CT = internal bond for cyclic test; TS = thickness swelling; and WA = water absorption

\section{Effects of Species and Mixing}

In particleboard production, specific gravity is a crucial property that impacts the compaction ratio, which influences the mechanical and physical properties of the board. Lower specific gravity allows board compaction with less spring back, which yields a stable, high density final product with good bond strength (Haygreen and Bawyer 2003). When making particleboard from mixed species, the combination of particles having different specific gravity may have positive impact. The effects of individual and species mixing on particleboard properties are compared in Fig. 4. Particleboard made from 100\% NC gave higher modulus of elasticity (MOE) and modulus of rupture (MOR) values than 50:50 mixed species and 100\% LL particleboards. Babatunde et al. (2008) showed the same trends where boards made from LL, a high specific gravity wood species have lower mean values and strength when compared with boards made from Gmelina arborea, a low specific gravity wood species. The particle size distribution of LL with more fines would also translate to lower bending flexibility. The significant reduction of MOE and MOR when $100 \%$ LL was used confirms this.

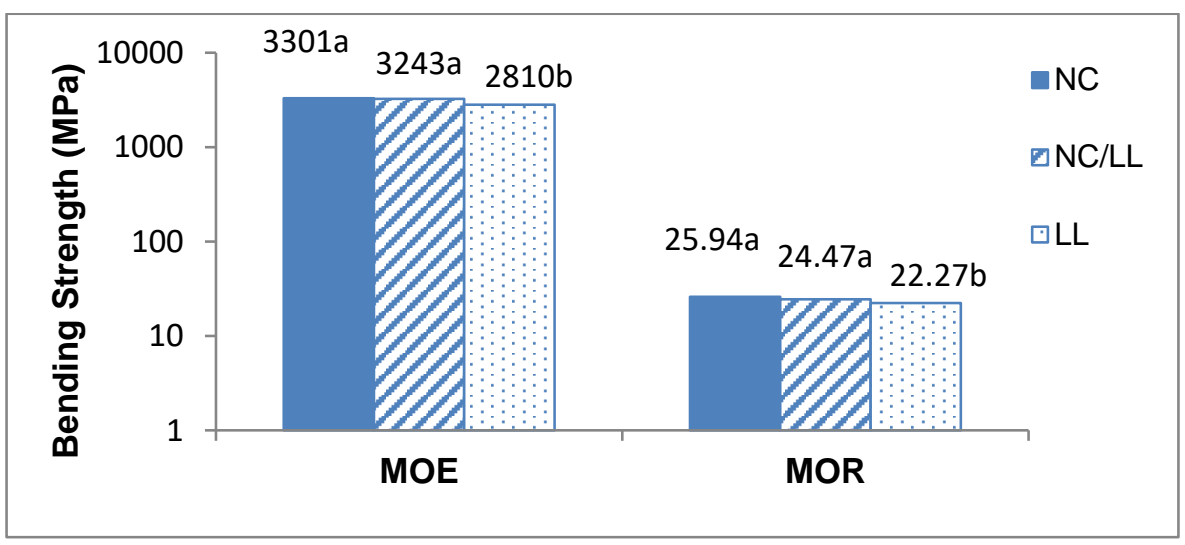

Fig. 4. $M O E$ and $M O R$ of the particleboards. Entries $N C, N C / L L$, and LL denote mixing ratio; and letters $a$, and $b$ indicate values in cluster to be significantly different at $p \leq 0.05$. 
Figure 5 shows the effects of species mix on IB and IB CT. Particleboard made from NC gave the highest value of IB and IB CT, while particleboard made from LL gave the lowest value. According to Imtiaz et al. (2014), the high specific gravity of raw material also results in a more porous mat structure than that for wood panels, which results in a lower surface area for resin bonding. Poor resin penetration along with low surface area reduces the bonding strength (Nemli 2003; Tabarsa et al. 2011). Chow et al. (1986) stated that the decreased of strength properties in IB-CT due to accelerated aging test in hardwood composite panels may be attributed to thickness swelling and the deterioration of the glue bond, as a result of springback that results in lower density of board. The IB reduction of $\mathrm{NC}, \mathrm{NC}+\mathrm{LL}$, and LL were $60 \%, 67 \%$, and $71 \%$, respectively. This is an inverse relationship to the specific gravity of the particles use. Another potential factor that could lower the IB reading for LL is the fact that it has higher buffering. The buffering slows down curing, especially when using MUF as a binder (Policardi and Thebault 2020). The significant IB reduction once the LL had been added indicates the need to modify the resin cures time prior to bonding.

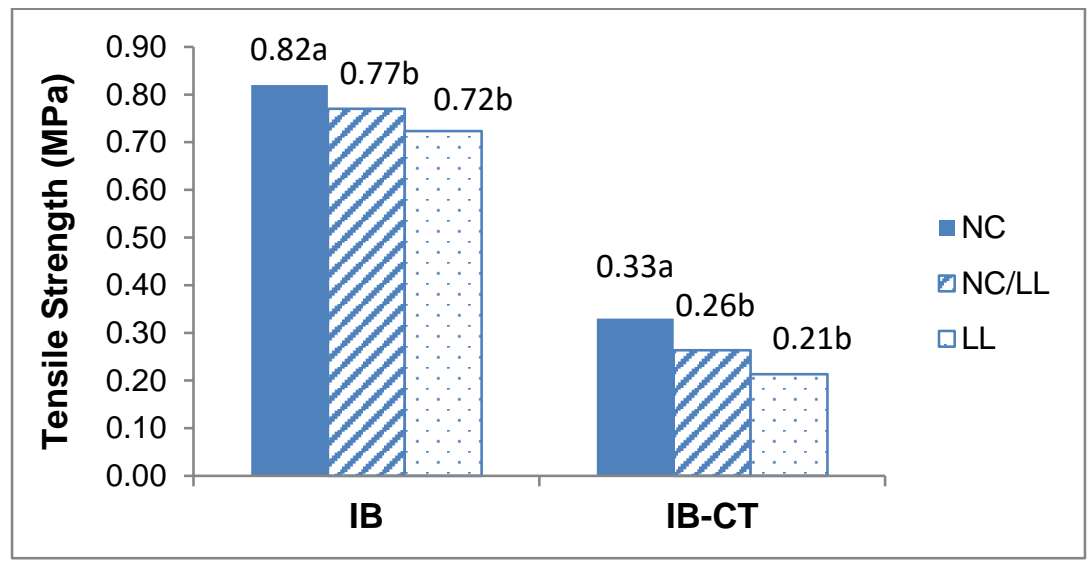

Fig. 5. IB and IB-CT of the particleboards with species mix: Entries NC, NC/LL, and LL denote mixing ratio; and letters $a$, and $b$ indicate values in cluster to be significantly different at $p \leq 0.05$.

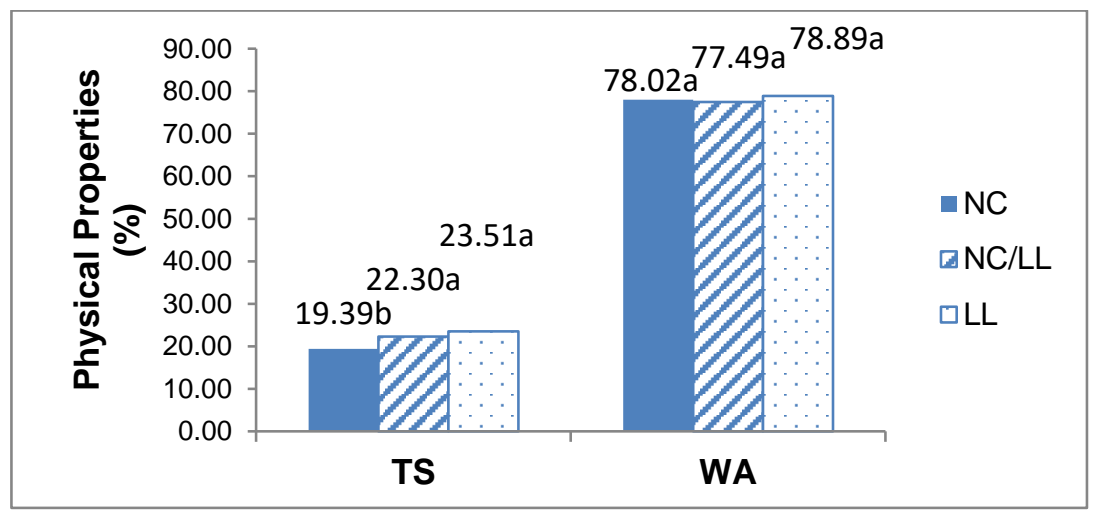

Fig. 6. TS and WA of the particleboards with different species mix. Entries NC, NC:LL, and LL denote mixing ratio; and letters $a$, and $b$ indicate values in cluster to be significantly different at $\mathrm{p} \leq 0.05$.

The TS and WA behaviors of test combinations are shown in Fig. 6. Particleboard made from NC gave the lowest TS value (significant at $\mathrm{p} \leq 0.05$ ) compared with mixed species and LL, reflecting its compactness. The WA showed no significant difference for 
all combinations, though in actual value the NC performed better. The lower density wood provides a high density compaction rate and, therefore, a higher contact surface between the particles than high density wood (Elbadawi et al. 2015). Uncompacted particleboard develops more irregular voids in between the particle during the formation, thus enhancing the water absorption and thickness swelling of boards (Sotannde and Oluwadare 2012).

\section{Effects of Resin Content}

The resin content impact for the neat and combined particleboard does not differ much from previous reports, where for each combination of the MOR and MOE had a proportional relationship to the resin content (Ratkhe et al. 2012; Salari et al. 2013). Thus, as per theory the $14 \%$ resin content performed the best compared to $12 \%$ and $10 \%$ for $\mathrm{MOE}$ and MOR (Fig. 7). With increasing resin content, the coverage of particles increased, leading to better surface interaction, reflected by the MOR and IB (Fig. 8).

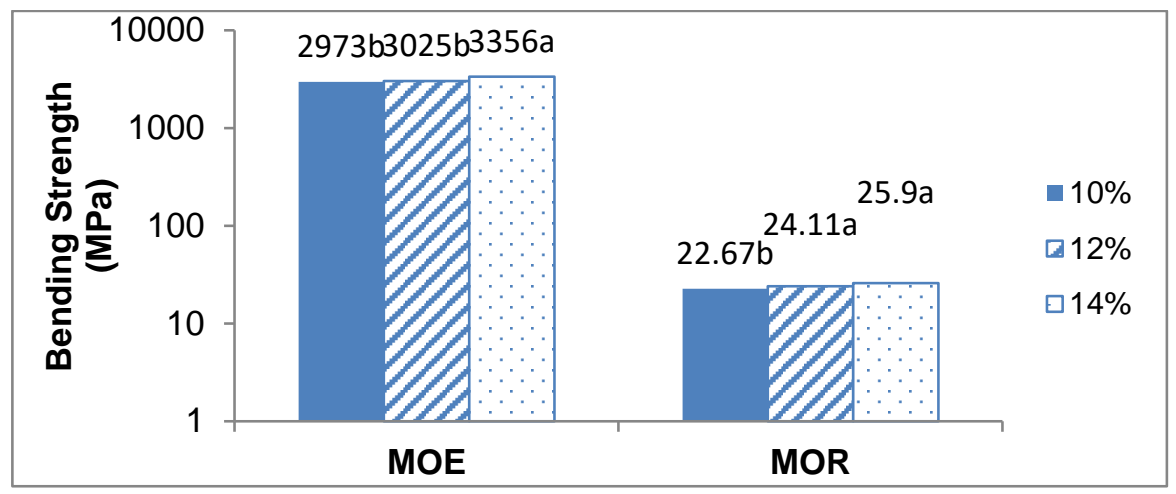

Fig. 7. MOE and MOR of the particleboards made with different resin content: Entries 10, 12, and 14 represent resin content; different letters $a, b$, and $c$ indicates values in a cluster to be significantly different at $p \leq 0.05$.

Figure 8 indicates that the IB for the resin dosage for $10 \%$ was significantly lower than the other two dosages. Dosages at 12 and $14 \%$ were not significantly different. For standard board usage, $12 \%$ resin gave sufficient IB, and cost saving could be achieved. When subjected to cyclic test, which represents a high moisture environment, the IB-CT showed that the $2 \%$ extra dosage would give significant difference in performance. Overall, the IB and IB-CT showed a significant proportional relationship to resin percentage.

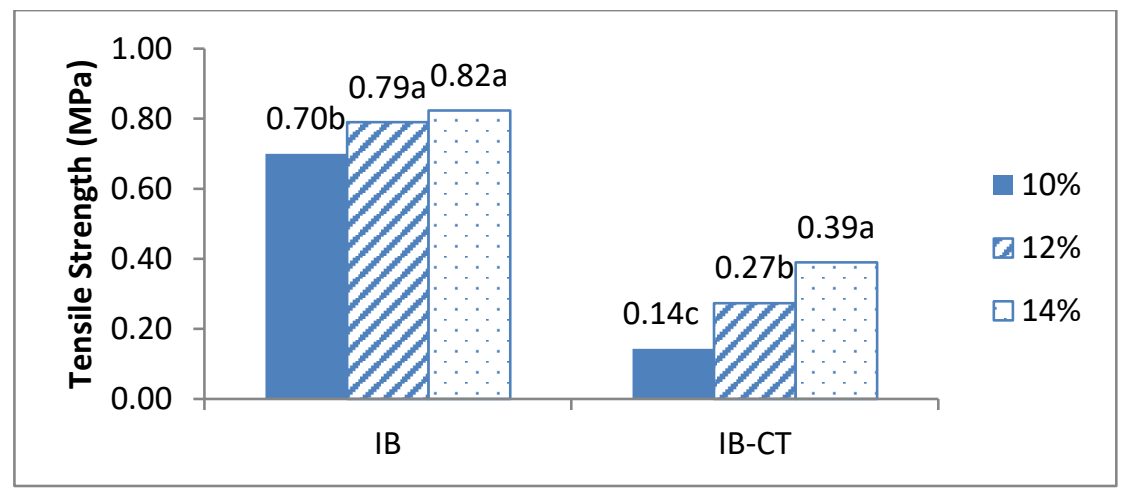

Fig. 8. IB and IB-CT of the particleboards made with different resin content: Entries 10, 12, and 14 represent resin content; and different letters $\mathrm{a}, \mathrm{b}$, and $\mathrm{c}$ indicate values in cluster to be significantly different at $p \leq 0.05$. 
The impact of resin content on thickness is significant, as can be seen in the lowering of swelling by $27 \%$ compared to the $16 \%$ increment in resin used. The water absorption did not display the same reduction (only 15\%) for the 14\% dosage (Fig. 9). The lowering of swelling shows that the bonding resulting from the resin was strong enough to resist the bulking effect, which resulted from absorbed water orientation. The $10 \%$ resin dose resulted in the lowest performance. The absorption for 12 and $14 \%$ were not significantly different. The swelling was different and was reflected in the IB-CT reading differential shown in Fig. 8. The reduction in swelling was even at $13 \%$ as the resin increased. Having a higher dosage should reduce the thickness swelling further. Melamine urea formaldehyde is a high moisture resistant resin; it resists hydrolysis to a good extent. The issue of high absorption cannot be resolved by resin alone. Low reduction of water intake of only $4 \%$ moving from 12 to $14 \%$ indicates that the porosity in the particleboard will still allow absorption of water close to $70 \%$ even if the resin content is increased. The addition of wax is likely to improve the absorption level, as the hydrophobic nature of wax would repel water.

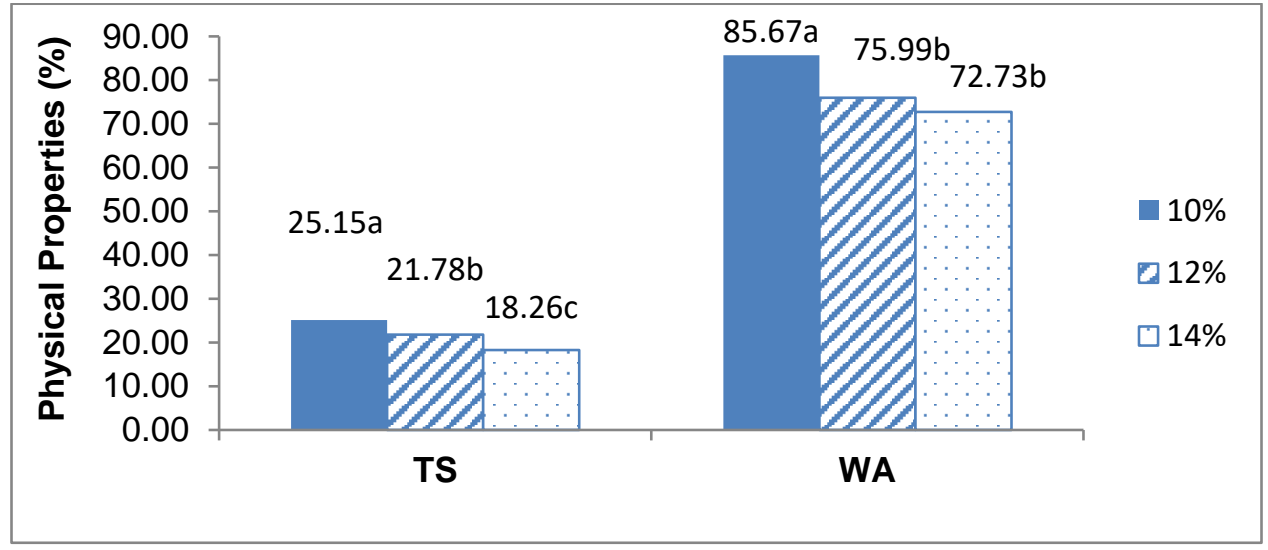

Fig. 9. TS and WA of the particleboards made with different resin content: Entries 10, 12, and 14 represent resin content; and letters a, b and c indicate values in cluster to be significantly different at $\mathrm{p} \leq 0.05$.

\section{CONCLUSIONS}

1. All boards made with the exception of $100 \%$ LL met the EN312 minimum requirement for mechanical strength. The potential of the N. cadamba and L. leucocephala mixture in particleboard manufacturing was shown by evaluating the mechanical properties of the board. However more work is needed for improvement of the thickness swelling (TS) values.

2. When comparing the different species, $N$. cadamba with $14 \%$ resin content gave best overall performance.

3. Combination optimization of these species could be further explored; this would allow planned planting volume of $N$. cadamba and L. leucocephala, if it is to be a viable continuous resource for the industry. 


\section{ACKNOWLEDGEMENTS}

The authors thank the Center of Wood Industries of Universiti Teknologi MARA Pahang (Jengka) for the facilities used in study. Gratitude is also extended to Malayan Adhesives and Chemicals (MAC) Sdn Bhd. for supplying the resin used in this research.

\section{REFERENCES CITED}

Babatunde, A., Olufemi, B., Fuwape, J. A., and Badejo, S. O. (2008). "Effect of wood density on bending strength and dimensional movement of flake boards from Gmelina arborea and Leuceana leucocephala," in: $11^{\text {th }}$ Int. Inorganic-Bonded Fiber Composites Conference, Madrid, Spain.

Babinski, L., Izdebska-Mucha, D., and Waliszewska, B. (2014). "Evaluation of the state of preservation of waterlogged archaeological wood based on its physical properties: Basic density vs. wood substance density," Journal of Archaeological Science 46, 372-383. DOI: 10.1016/j.jas.2014.03.038

Chow, P., Janoviak, J. J., and Price, E. W. (1986). "The internal bond and shear strength of hardwood veneered particleboard composites," Wood Fiber Science 18(1), 99-106

Elbadawi, M., Osman, Z., Paridah, T., Nasroun, T., and Kantiner, W. (2015). "Mechanical and physical properties of particleboards made from Ailanthus wood and UF resin fortified by acacias tannins blend," Journal of Materials and Environmental Science 6(4), pp. 1016-1021

EN 15149-1 Standard (2010). "Solid biofuels - Determination of particle size distribution - Part 1: Oscillating screen method using sieve apertures of $1 \mathrm{~mm}$ and above," CEN European Committee for Standardization, p. 18.

EN 310. (2003). "Wood-based panels. Determination of modulus of elasticity in bending and of bending strength," European Committee for Standardization, Brussels, Belgium.

EN 312. (2003). "Particleboards - Specifications," European Committee for Standardization, Brussels, Belgium.

EN 317. (2003). "Particleboards and fiberboards. Determination of swelling in thickness after immersion in water," European Committee for Standardization, Brussels, Belgium.

EN 319. (2003). "Particleboard and fibreboard. Determination of tensile strength perpendicular to the plane of the board," European Committee for Standardization, Brussels, Belgium.

EN 321. (2002). "Wood-based panels - Determination of moisture resistance under cyclic test conditions," European Committee for Standardization, Brussels, Belgium.

Guo, Q., Chen, X., and Liu, H. (2012). "Experimental research on shape and size distribution of biomass particle," Materials Science-Fuel 94, 551-555.

DOI:10.1016/J.FUEL.2011.11.041

Haygreen, J. G., and Bawyer, J. L. (2003). Forest Products and Wood Science: An Introduction, Fourth Edition. Blackwell Publishing, pp. 201-415.

Imtiaz, A., Jayaraman, K., and Bhattacharyya, D. (2014). "Effects of resin and moisture content on the properties of medium density fibreboards made from kenaf bast fibres," Industrial Crops and Products 52, 191-198.

DOI:10.1016/j.indcrop.2013.10.013 
ISO 3131 (1975). “ Wood - Determination of density for physical and mechanical tests", International Organization for Standardization.

Jamaludin, K., Nur Sakinah, M. T., Nur Farahin, Y., Wan Mohd Nazri, W. A. R., Nurrohana, A., and Nor Yuziah, M. Y. (2018). "Impact of alkaline treatment on mechanical properties and thickness swelling of exterior particleboard made from kelempayan (Neolamarckia cadamba) wood," Regional Conference on Science, Technology and Social Sciences, Springer Nature Singapore Pte Ltd. Pp. 787-797.

Lim, S. C., Can, K. S., and Thi, B. K. (2005). "Identification and utilization of lesserknown commercial timbers in Peninsular Malaysia," Timber Technology Bulletin, Timber Technology Centre, FRIM, 32, pp. 139-258.

Malaysian Timber Industry Board (2017). "Malaysian timber E-stats,"

Malaysian Timber Industry Board (MTIB) (2000). 100 Malaysian Timbers, Third Reprint, Malaysian Timber Industry Board, Kuala Lumpur, pp. 223-224.

Muhammad Zulhilmi, R. (2019). "Properties of high moisture resistance particleboard from Leucaena leucocephala," Master's Thesis, Universiti Teknologi MARA, Malaysia

Nemli, G. (2003). "Effects of some manufacturing factors on the properties of particleboard manufactured from alder (Alnus glutinosa subsp. Barbata)," Turkish Journal of Agriculture and Forestry 27, 99-104.

Policardi, F., and Thebault, M. (2020). "The buffer effect of different wood species and the influence of oak on panel composites binders," Polymers 12, 1540

Ratkhe, J., Sinn, G., Harm, M., Teischinger, A., Weigl, M., and Müller, U. (2012). "Effects of alternative raw materials and varying resin content on mechanical and fracture mechanical properties of particleboard," BioResources 7(3), 2970-2985. DOI: 10.15376/biores.7.3.2970-2985

Salari, A., Tabarsa, T., Khazaeian, A., and Saraeian, A. (2013). "Improving some of applied properties of oriented strand board (OSB) made from underutilized low quality paulownia (Paulownia fortunie) wood employing nano-SiO 2 ," Ind. Crop. Prod. 42, 1-9. DOI: 10.1016/j.indcrop.2012.05.010

Tabarsa, T., Ashori, A., and Gholamzadeh, M. (2011). "Evaluation of surface roughness and mechanical properties of particleboard panels made from bagasse," Composites Part B: Engineering 42, 1330-1335. DOI: 10.1016/j.compositesb.2010.12.018

TAPPI T204 Cm-97 (1997). "Solvent extractives of wood and pulp," TAPPI Press, Atlanta GA.

TAPPI T207 Cm-99 (1999). "Water solubility of wood and pulp," TAPPI Press, Atlanta ,GA.

TAPPI T 211 Om-02 (2002). "Ash in wood, pulp, paper and paperboard: Combustion at $525^{\circ} \mathrm{C}$," TAPPI Press, Atlanta, GA.

TAPPI T 212 Om-02 (2002).“'One percent sodium hydroxide solubility of wood and pulp," TAPPI Press, Atlanta, GA.

TAPPI T222 om-02 (2002). “Acid-insoluble lignin in wood and pulp,” TAPPI Press, Atlanta, GA.

TAPPI T 203 Cm-99 (1999). “Alpha-, beta- and gamma-cellulose in pulp,” TAPPI Press, Atlanta, GA.

TAPPI T 258 om-02 (2006). "Moisture in wood, pulp, paper and paperboard by toluene distillation," TAPPI Press, Atlanta, GA.

Trianoski, R., Iwakiri, S., and de Matos, J. L. M. (2011). "Potential use of planted fastgrowing species for production of particleboard," Journal of Tropical Forest Sciences 
23(3), 311-317.

Tumuluru, J. S., Wright, C. T., Hess, J. R., and Kenney, K. L. (2011). “A review of biomass densification systems to develop uniform feedstock commodities for bioenergy application," Biofuels, Bioproducts and Biorefining 5, 683-707. DOI: 10.1002/bbb.324

Wahab, R., Mohamed, A., Mustafa, M. T., and Hassan, A. (2009). "Physical characteristics and anatomical properties of cultivated bamboo (Bambusa vulgaris Schrad.) culms," Journal of Biological Sciences, 9(7), pp. 753-759. DOI:10.3923/jbs.2009.753.759

Wan Mohd Nazri,W. A. R, Azematul Asma, M. Y., Ahmad Afiq, M. Z., Jamaludin Kasim and Nor Yuziah, M. Y. (2019). "Effect of resin content and particle size on the properties of particleboard made of Neolamarckia and Leuceana particles" BioResources 14(3) 6079-6087.

Wan Mohd Nazri, W. A. R., Muhammad Fitri, S., Suffian, M., Nur Nazihan, S., and Nor Yuziah, M. Y. (2020). "Wood and veneer properties of fast growing species from batai, eucalyptus and kelampayan" International Journal of Management and Humanities 4(8), 65-71

Xing, C., Zhang, S. Y., and Deng, J. (2004). "Effect of wood acidity and catalyst on UF resin gel time," Holzforschung 58, 408-412. DOI: 10.1515/HF.2004.061

Zhang, J., and Guo, Y. (2014). "Physical properties of solid fuel briquettes made from Caragana korshinskii Kom," Powder Technology 256, 293-299.

DOI:10.1016/j.powtec.2014.02.025

Article submitted: June 22, 2021; Peer review completed: October 9, 2021; Revised version received and accepted: November 5, 2021; Published: January 28, 2022.

DOI: $10.15376 /$ biores.17.1.1868-1880 